INTRODUCTION TO SYMPOSIUM:

CELEBRATING THE CENTENARY OF KEYNES'S TREATISE ON PROBABILITY

BY BRADLEY W. BATEMAN*

* Randolph College, Lynchburg. E-mail: bbateman@randolphcollege.edu

This "preprint" is the peer-reviewed and accepted typescript of an article that is forthcoming in revised form, after minor editorial changes, in the Journal of the History of Economic Thought (ISSN: 1053-8372), issue TBA. Copyright to the journal's articles is held by the History of Economics Society (HES), whose exclusive licensee and publisher for the journal is Cambridge University Press.

(https://www.cambridge.org/core/journals/journal-of-the-history-of-economic-thought) This preprint may be used only for private research and study and is not to be distributed further.

The preprint may be cited as follows:

Bateman, Bradley W. Introduction to Symposium: Celebrating the Centenary of Keynes's Treatise on Probability. Journal of the History of Economic Thought (forthcoming). Preprint at SocArXiv, osf.io/preprints/socarxiv 


\section{Introduction to Symposium: \\ Celebrating the Centenary of Keynes's Treatise on Probability}

Bradley W. Bateman ${ }^{1}$

While 2021 marks the hundredth anniversary of the publication of John Maynard Keynes's Treatise on Probability, it was not until roughly thirty five years ago that serious scholarship in the history of economic thought began to examine the connections between his early work in the philosophy of uncertain knowledge and his later work as an economic theorist. When the Royal Economic Society, for instance, set about to honor Keynes's contributions by publishing his Collected Writings, they did not think it worthwhile to include the correspondence concerning his work in probability and this decision reflected the way that the profession weighed Keynes's philosophical work as unimportant to understanding his economics at the time. ${ }^{2}$ The cause(s) of the profession's neglect of this part of Keynes's work for so long is almost certainly overdetermined, but one of the major contributors was that the mainstream, neoclassical Keynesian economics that emerged in the postwar world did not contain expectations as an important component of its analysis. If "Keynesian economics" was not concerned with uncertainty, why would his early work on uncertain knowledge reveal anything to us about his economics?

The neglect of Keynes's work in philosophy began to shift in the 1980s with two Cambridge dissertations by Anna Carabelli and Rod O'Donnell, which were subsequently revised and published as books (Carabelli 1988, O'Donnell 1989). By the 1980s, historians of economic thought had become increasingly interested in intellectual history as a model for their work, rather than simply looking to the frontiers of mainstream economics to define their work; thus, scholars began researching the full range of Keynes's work, from his philosophical interests (Bateman 1987, 1988; Davis 1994; Runde 1994), to his work in economic policy making and investing (Clarke 1987). Suddenly, there was a different, fuller kind of interest in understanding the things that influenced Keynes's work as an economist and this change came from many directions.

When the editors of this Journal approached me to organize a symposium to celebrate the centenary of Probability, however, I sought not to re-cap the early years of scholarship, but to look for new work on this aspect of Keynes's thought. What has happened in the most recent decade of scholarship on Probability?

Arguably the most ground-breaking work in this area in the last ten years has been Jeff Biddle's exploration of the way that Keynes's book shaped empirical work in the United States in the 1920s. Biddle's essay in this symposium documents how Probability influenced the way that several leading American statisticians understood "good method" in their empirical work,

\footnotetext{
${ }^{1}$ Randolph College, Lynchburg, VA 24503.

${ }^{2}$ See Robinson (1990) and Moggridge (1997).
} 
especially inductive work based on economic time series data. Biddle then goes on to discuss how Keynes's ideas regarding "inferential methods based on probability theory" shaped the empirical work of several leading American agricultural economists.

Sylvie Rivot has been working on another frontier of scholarship focusing on Keynes's work on probability. Traditionally, scholarship on the influence(s) of Probability on Keynes's work as an economist has focused on the connections to his work as an economic theorist. Rivot, however, has chosen to explore how his work on probability affected his outlook on economic policy. Looking over the arc of his career, she finds in her contribution to the symposium that Keynes was concerned not only with people's expectations, but also with the confidence with which they hold them. This distinction reflects, of course, Keynes's distinction between probabilities and the weight we place on them. Seen through this frame, Rivot provides the reader with a fresh view of Keynes's thinking on the relative roles of fiscal and monetary policy.

The third contribution to the symposium draws on two recent contributions to our understanding of Keynes's work: Robert Shiller's (2019) work on narrative economics and Cheryl Misak's recent work (2020) on the influence of Frank Ramsey on Cambridge economics. My own essay in this symposium considers Keynes's use of narrative beyond Shiller's limited examination of The Economic Consequences of the Peace (1920) and places this in the fuller context of Frank Ramsey's pragmatism. This provides yet another lens through which to understand Keynes's shift from the objective theory of probability in Probability to his use of an intersubjective theory of probability in his economic theory after 1932.

When the celebration of the fiftieth anniversary of Keynes's General Theory of Employment, Interest, and Money took place in 1986, scholarly interest in the centrality of uncertainty and expectations to his magnum opus was a relatively new enterprise. When we celebrate the General Theory's hundredth anniversary in 2036, however, the foci will undoubtedly have changed. There is no doubt, for instance, that our understanding of Keynes's work in probability theory will have continued to evolve and there is also no doubt that this work will influence our retrospective understanding of what Keynes meant to do in his work in economics. That's how intellectual history works.

\section{References:}

Bateman, Bradley (1987) "Keynes's Changing Conception of Probability." Philosophy and Economics 3 (1): 97-119.

Bateman, Bradley (1988) "G.E. Moore and J.M. Keynes: A Missing Chapter in the History of the Expected Utility Model." American Economic Review 78 (5): 1098-1106.

Carabelli, Anna (1988) On Keynes 's Method. London: Macmillan. Clarke, Peter (1988) The Keynesian Revolution in the Making, 1924-1936. Oxford: Oxford University Press. 
Davis, John (1994) Keynes s's Philosophical Development. Cambridge: Cambridge University Press.

Keynes, J.M. (1920) Economic Consequences of the Peace. London: Macmillan.

Keynes, J.M. (1921) Treatise on Probability. London: Macmillan.

Keynes, J.M. (1936) The General Theory of Employment, Interest, and Money. London:

Macmillan.

Misak, Cheryl (2020) Frank Ramsey: An Excess of Powers. Oxford: Oxford University Press.

Moggridge, Donald E. (1997) "Among the most fascinating of scholarly objects: a memoir."

Journal of the History of Economic Thought 19 (1): 24-48.

O'Donnell, Roderick (1989) Keynes: Philosophy, Economics and Politics. London: Macmillan.

Robinson, Austin (1990) Fifty-five years on the Royal Economic Society Council, in John D. Hey and Donald Winch, eds. A Century of Economics: A Hundred Years of the Royal Economic Society and the Economic Journal. Oxford: Blackwell. Pp 161-92.

Runde, Jochen (1994) "Keynes after Ramsey: In Defence of $A$ Treatise on Probability." Studies in the History and Philosophy of Science Part A 25 (1):97-121.

Shiller, Robert (2019) Narrative Economics How Stories Go Viral and Drive Major Economic Events. Princeton: Princeton University Press. 